\title{
Title: Reliability Analysis of the application of a catalogue of tutored and evaluable activities as a system to structure the contents of the so -called courses End of Degree or/and Master Project, "EDMP".
}

\author{
M. Suffo ${ }^{1}$, J.L. García-Morales ${ }^{2}$, \\ ${ }^{1}$ Department of mechanical engineering and industrial design, Science Faculty, Campus de Puerto Real, Universidad de Cádiz, Polígono Río San Pedro \\ s/n 11510, Puerto Real (Cádiz), España. \\ 2Departament of environmental technologies, Faculty of marine and environmental sciences., Campus de Puerto Real, Universidad de Cádiz, \\ Polígono Río San Pedro s/n 11510, Puerto Real (Cádiz), España. \\ miguel.suffo@uca.es
}

\begin{abstract}
Even before the enactment of the new university regulatory framework defined in Europe by the "Bologna process", the University of Cadiz "UCA" (South-Spain) carried out pilot experiences to develop the accomplishment of final reports of several university degrees or/and masters. One of the first conclusions to be drawn from these first written reports was the significant arbitrariness and the disparities that defined the contents and methodology of the new courses called End Degree or/and Master Project (EDMP) included in the modules so appointed. In order to unify criteria and implement these experiences, it was then necessary to design a catalogue of training and tutored activities, to be used as a basis to assess the EDMP's contents. Once the catalogue was designed, one subject was selected for its implementation. Finally, a rubric document was also applied to analyze the reliability of the evaluation and selection criteria, which was based on aspects such as the public presentation of works or performing a technical research. Results revealed that the original assessment criteria proposed may not be the most appropriate.
\end{abstract}

KEYWORDS: "rubric documents", "undergraduate education “, "cooperative learning”, "multilevel evaluation”, "Reliability analysis".

\section{INTRODUCTION}

The entry into force of the new legal framework to regulate university studies in Spain through the Bologna process has implied redefining the current configuration of different degrees (Rezaev, 2010) (Sakarya \& Kahraman, 2011). Degrees are generally structured in five modules that must contain new materials to complete a total of 240 credits in four years. During the final year of the degree, a module identified as End-of-Degree Project (EDP) has been defined; this could be decomposed into basic materials to complete a range of between 6 and 30 credits. Such materials or subjects represent the suitable candidates for the development of various activities and resources in order to provide contents and methods. Subjects are taken at the final stage of the study plan and should be aimed at assessing the skills associated with the degree (Salán, Martinez-Martinez, Portet, \& Torra, 2012).

Motivated by the lack of references and previous standards, each study plan has tried to guide the content of this module and its materials in order to suit their own profile depending on whether they are mainly scientific, humanistic or technological. This practice has led to a number of discrepancies when preparing the degrees' reports, especially in regard to this type of materials. To illustrate this scenario, a comparison between the contents of some of the FRs has been performed with respect to some of the degree courses offered by the UCA, which is summarized in Table 1.

Table 1. Comparison between the definitions of the materials in different memories EDP titles within the UCA. 


\begin{tabular}{|c|c|c|c|c|c|c|c|c|c|c|}
\hline & Grades & Modules & Materials & Credits & NoS & Competences & Evaluation & Results Competencies & \begin{tabular}{c|} 
Admission \\
Requirements
\end{tabular} & Contents \\
\hline 1 & ES & TEKAT & PeD & 6 & 8 & $\begin{array}{l}\text { Basics, specifics and } \\
\text { transversals }\end{array}$ & $\begin{array}{l}\text { Written Memory, } \\
\text { public defense and } \\
\text { oral }\end{array}$ & $\begin{array}{l}\text { needed to comply with the } \\
\text { evaluation system }\end{array}$ & $\begin{array}{l}\text { All basics and } \\
\text { fundamentals }\end{array}$ & \begin{tabular}{|l|} 
training activities non- \\
presential forms and invidual \\
works about ambiental \\
sciences
\end{tabular} \\
\hline 2 & MS & PROJECT & PeD & 6 & 8 & $\begin{array}{l}\text { Basics, specifics and } \\
\text { transversals }\end{array}$ & $\begin{array}{l}\text { Written Memory, } \\
\text { public defense and } \\
\text { oral }\end{array}$ & $\begin{array}{l}\text { needed to comply with the } \\
\text { evaluation system }\end{array}$ & $\begin{array}{l}\text { All basics and } \\
\text { fundamentals }\end{array}$ & \begin{tabular}{|l|} 
training activities non- \\
presential forms and invidual \\
works about marine sciences
\end{tabular} \\
\hline 3 & $\mathrm{ChS}$ & PROJECTS & WeD & 15 & 8 & Basics and specifics & $\begin{array}{l}\text { oral presentation and } \\
\text { defense }\end{array}$ & $\begin{array}{l}\text { Capacity to defend oraly their } \\
\text { work. Ability to develop scientific } \\
\text { reports }\end{array}$ & $\begin{array}{l}\text { To admission: } \\
>162 \text {. To oral } \\
\text { defense: All of } \\
\text { them }\end{array}$ & $\begin{array}{l}\text { Trabajos de introducción a la } \\
\text { investigación o actividades } \\
\text { que se determinen }\end{array}$ \\
\hline 4 & MAT & WeD & WeD & 12 & 7,8 & $\begin{array}{l}\text { Some generals and all } \\
\text { transversals }\end{array}$ & $\begin{array}{l}\text { oral presentation and } \\
\text { defense }\end{array}$ & $\begin{array}{l}\text { Ability to search information. } \\
\text { Oral and written presentation } \\
\text { works }\end{array}$ & $\begin{array}{l}\text { To admission: } \\
>162 \text {. To oral } \\
\text { defense: All of } \\
\text { them }\end{array}$ & $\begin{array}{l}\text { Work or Project about fields } \\
\text { degree. It is obligatory to add } \\
\text { some abstract in the other } \\
\text { language }\end{array}$ \\
\hline 5 & BA & $\begin{array}{l}\text { Professional } \\
\text { Proyection }\end{array}$ & WeD & 6 & 8 & \begin{tabular}{|l|} 
To search, analysis and \\
synthesis of information. \\
Oral y written \\
presentation
\end{tabular} & $\begin{array}{l}\text { Development and } \\
\text { defense of works }\end{array}$ & $\begin{array}{l}\text { Applying the knowledge they } \\
\text { have acquired. Applying } \\
\text { processes and information } \\
\text { collection. To understand a } \\
\text { cuestion criticaly }\end{array}$ & $N / D$ & $\begin{array}{l}\text { the student's autonomous } \\
\text { work and presentation of the } \\
\text { integrated knowledge exercise }\end{array}$ \\
\hline 6 & LAR & WeD & Wed & 6 & 8 & $\begin{array}{l}\text { Some generals and all } \\
\text { transversals }\end{array}$ & $\begin{array}{l}\text { Monitoring to tutor } \\
\text { and evaluating to } \\
\text { comission }\end{array}$ & $\begin{array}{l}\text { Oral and written presentation } \\
\text { works }\end{array}$ & \begin{tabular}{|l|}
$>60$ basic credits \\
and 120 \\
obligatorys
\end{tabular} & $\begin{array}{l}\text { Works or memory about fields } \\
\text { degree }\end{array}$ \\
\hline 7 & HIS & WeD & Wed & 6 & 8 & All basics and specifics & $\begin{array}{l}\text { Monitoring to tutor } \\
\text { and evaluating to } \\
\text { comission }\end{array}$ & $\begin{array}{l}\text { To demonstrate its } \\
\text { communication skills in oral } \\
\text { presentations in spanich language } \\
\text { in professional situations }\end{array}$ & None & $\begin{array}{l}\text { the student's autonomous } \\
\text { work. Activities directed. Oral } \\
\text { presentations }\end{array}$ \\
\hline 8 & LIN & WeD & WeD & 6 & 8 & All specifics & $\begin{array}{l}\text { written tests of } \\
\text { theoretical and } \\
\text { practical knowledge. } \\
\text { Oral presentations. } \\
\text { Tutoring }\end{array}$ & $\begin{array}{l}\text { Has a work of at approximately } \\
150 \text { pages. }\end{array}$ & \begin{tabular}{|l}
$>60$ basic cre dits \\
and 120 \\
obligatorys
\end{tabular} & $\begin{array}{l}\text { training activities. theoretical } \\
\text { and practical classes. Tutoring }\end{array}$ \\
\hline 9 & AAIS & WeD & WeD & 6 & 8 & All specifics & $\begin{array}{l}\text { to make an oral } \\
\text { presentation to the } \\
\text { Commission with the } \\
\text { next members: } \\
\text { director of work and } \\
\text { two experts }\end{array}$ & $\begin{array}{l}\text { Reaching critical maturity about a } \\
\text { research project }\end{array}$ & \begin{tabular}{|l}
$>60$ basic credits \\
and 120 \\
obligatorys
\end{tabular} & ADA, non presentials \\
\hline 10 & $\mathrm{PHY}$ & WeD & Wed & 6 & 8 & $\begin{array}{l}\text { Capacity to development } \\
\text { a report and a public } \\
\text { presentation and } \\
\text { defense }\end{array}$ & Public defense & $N / D$ & $\begin{array}{l}\text { Having approved } \\
\text { all the above } \\
\text { subjetcs }\end{array}$ & $\begin{array}{l}\text { Development a integrated } \\
\text { exercise among the training } \\
\text { content covered }\end{array}$ \\
\hline 11 & MED & WeD & Wed & 6 & 11,12 & $\begin{array}{l}\text { Has been gained } \\
\text { experience about } \\
\text { assessment and self- } \\
\text { assessment }\end{array}$ & $\begin{array}{l}\text { Public defense and the } \\
\text { english language is } \\
\text { admitted as main } \\
\text { language }\end{array}$ & \begin{tabular}{|l|} 
Learn to use clinical and \\
biomedical references; \\
Interpreting scientific texts; \\
Disegn and developmen basic \\
statistical studies and a public \\
defense oral and written an \\
original case-study or profesional \\
report
\end{tabular} & $\begin{array}{l}\text { Having approved } \\
\text { all the above } \\
\text { subjetcs }\end{array}$ & WeD presentation \\
\hline 12 & ChE & WeD & WeD & 18 & 8 & $\begin{array}{l}\text { to demonstrate } \\
\text { capacities to written and } \\
\text { developmen projects }\end{array}$ & $\begin{array}{l}\text { Presentation the some } \\
\text { chemical enginering } \\
\text { project for the defense } \\
\text { by Assessment } \\
\text { Tribunal }\end{array}$ & $\begin{array}{l}\text { Synthesize and integrate own } \\
\text { competences of degree }\end{array}$ & $\begin{array}{l}\text { To admission: } \\
>162 \text {. To oral } \\
\text { defense: All of } \\
\text { them }\end{array}$ & $\begin{array}{l}\text { Develop a original exercise } \\
\text { like a chemical engineering } \\
\text { project }\end{array}$ \\
\hline
\end{tabular}

\begin{tabular}{llll} 
ES: & Environmental Sciences & NoS: & Number of Semester \\
MS: & Marine sciences & WeD: & Work end degree \\
ChS: & Chemical sciences & PeD & Project end degree \\
MAT: & Mathematics & TEKAT: & Transverse Environmental Knowledge and Techniques \\
BA: & Business Administration & N/D: & Not Defined \\
LAR: & Labor and Relationships & ADA: & Academically Directed Activities \\
HIS: & History & & \\
LIN: & Linguistics & & \\
AAIS: & Arab and Islamic Studies & & \\
PHY: & Physiotherapy & & \\
MED: & Medicine & & \\
ChE: & chemical engineer & \\
\hline
\end{tabular}

After evaluating the 12 degrees listed in Table 1, the current status of the EDPs in each knowledge field (basic and applied sciences, humanities, medical sciences, social sciences and 
engineering) can be obtained. The analysis of the data included in Table 1 resulted in the following discrepancies between the Degrees:

- Five ways to name the WeD module

- Four different credit assignations to the subject

- Four ways to define the registration requirements.

- Seven different ways to fill the contents of the subjects to be taught in the modules.

- Two ways of referring to the matter within the Module: Work or Final Year Project.

On the other hand, matching aspects can be also found, such as the evaluation systems and the results of the skills assessed in the subject. In fact, most of the samples analyzed converged in these aspects, which are oriented towards the preparation and defense of a report or project that integrates the knowledge acquired during the development of the degree. Therefore, this course must be taught during the last term of the degree. Similarly, only two of the samples, the degrees corresponding to Linguistics and Arabic and Islamic studies, have included training or activities directed academically to their respective contents in order to cover the assigned credits.

The baseline scenario thus described, raises some uncertainties about the adequacy of suggesting contents mainly based on writing, presenting and defending an exercise, report or project carried out by the students (Lucas Yagüe et al., 2008). Such an activity is highly demanding for students who, on the other hand, haven't been properly prepared to conduct.

The approach presented here is intended to serve as a starting point for the development of such work, which, in the absence of standard contents aimed at assessing the skills acquired through this module, proposes the alternative implementation of a "Catalogue or Portfolio of Tutored and Evaluable Activities "as a framework for a more objective evaluation (Gaubatz \& Centra, 2000). Moreover, in section 3, we propose a rubric assessment that has been performed over the activities listed in the catalogue for a period of 3 academic years and by 180 undergraduate or master students. This type of assessments has been previously used by different authors (Dunbar, Brooks, \& Kubicka-Miller, 2006), (Delgado \& Fonseca-Mora, 2010). We have also conducted a reliability analysis of the main proposed evaluation criteria to assess the effectiveness of the final works, which is based on the submission of a technical report to a panel of teachers with responsibility in the area. The report is also forwarded to their fellows and any other expert who wishes to participate in the evaluation process. A reliability analysis was performed using the Cronbach's alpha statistical (Umphress, Lambert, Smart, Barlow, \& Clouse, 1997), (Iacobucci \& Duhachek, 2003) that determines whether the evaluation criteria for the final presentation of the project works are appropriate or whether they can be excluded owing to their poor overall contribution. This approach implies a reliable evaluation criterion by taking into account the evolution of this dynamic system. The multilevel assessment system used here poses a different polyhedral perspective, in which several evaluating agents use identical evaluation criteria in a similar manner to others applied previously (Apodaca \& Grad, 2005), (Nasser \& Hagtvet, 2006). 


\section{TEACHING METHODOLOGY.}

The teaching methodology proposed is aimed at the students to acquire the skills and strategies previously taught during the course through the achievement of activities that are preestablished in an initial evaluation rubric (Manlove, Lazonder, \& Jong, 2009), (Mulder, Lazonder, \& de Jong, 2011). During the process, theoretical basis of the content of the course are not weighted, as in past occasions. In contrast, specific stimuli proposed by tutored activities are used, which encourage the students to discover by themselves the most complex concepts related to their core labor (Soares, Sepúlveda, Monteiro, Lima, \& Dinis-Carvalho, 2013). During the development of the course, the students will plan a period of information searching during which they start generating their own documentation and knowledge while discarding useless data (Yeh, Yeh, \& Chen, 2012). This methodological proposal provides a counterpoint to methods based on the intensive use of the memory as the only learning tool. Teaching systems do not provide normally the most appropriate tools to meet the demands and requirements imposed by the Bologna Process, which states that this type of final courses should include an interaction between cross subjects areas in order to assess the skills acquired for each student during the whole training process (Van Der Merwe, 2002); (Huemann, Keegan, \& Turner, 2007).

The use of a "Catalogue or Portfolio of Tutored and Evaluable Activities" as the basis for the development of content and methods, is similar to the proposed project-based learning (Krajcik, J.S. \& Blumenfeld, 2006). The development of the catalogue with students implies, among others, the application of individual or group activities, the attendance to intensive seminars or additional technical contents, the writing of critical reports, visits to industries or commercial establishments or the management of technical documentation and regulations. Additionally, the method is based on a stimulus-based learning, which is conceived and organized to induce a "sharing in order to grow" mentality, as well as a sense of responsibility and autonomy (Yeh, Huang, \& Yeh, 2011), (Yeh, 2012). During the process of the implementation of the catalogue and in order to monitor the accomplishment of activities, faculties from different disciplines of the university and external experts participate under the role of a tutor. Also, certain milestones to be met by the students are established, which will determine the final score of the course (D. Chen, Li, \& Wang, 2014). The assessment system previously proposed to students is also considered as a tool for collaborative learning (Gómez-Ruiz, Rodríguez-Gómez, \& Ibarra-Sáiz, 2013).

The setting for conducting this experience was established during the last year of one of the degrees that is currently extinct within the Bachelor of Environmental Sciences. An existing course taught during the final year of the current study plan, the so-called "Organization and Project Management" was taken and restructured as a simulation of the future course called Final Project. The course consisted of 9 credits (90 hours) and was taught during the second semester of the fifth year of the degree.

Through this simulation, it was possible to develop a pilot framework able to check the methodology of the agents involved in the changes to be set up in the future degree. In this scenario of academic experimentation, we avoided the use of the classical evaluation methods for the "End of Degree Projects" (EDP) (Ragusa \& Lee, 2012), which have slightly varied in recent years (Bredin \& Söderlund, 2013). These deficiencies have been observed when students have 
been required to perform a public defense of a work, due largely to previous educational aspects, and despite having a considerable curricular load assigned.

One of the group activities that can be highlighted because of its good results is the technical visits to sites where students become familiar with the work systems necessary for shaping their projects, as a multilevel resource that is beneficial for a collaborative evaluation system (Başbay \& Ateş, 2009), (Frances Lawrenz, Thao, \& Johnson, 2012). This is far from the typical activity in which, without establishing a prior context or introductory premises, students are exclusively shown the inside of factory or plant and its major elements of production for a short time (Siu, 2007), (Markom et al., 2011). In contrast to this idea, the activity focuses on the formal approach to an environment where students discover, beforehand, the importance of attending the business in order to understand the debates and discussions that took place in the classroom. This visit serves as a center point to start their own critical report within a group where each student has to take a differentiated role, guided by the tutor, based on collaborative techniques. The work to be developed by students must be focused on one of the industries visited but applying different boundary conditions than those found in the site (Brennan, 2006).

The experience had a total of 15 groups or teams for each of the three academic years analysed. Every group was made up of four or five students. In the internal organization of each group, within the framework of the visits, the students were required to share, among themselves, the attendance to the appointments between the group members. Each group member was required to attend a minimum of two of the four scheduled visits each year. Students who attended more than the required amount of appointments were rewarded accordingly. Each group must be responsible for the attendance of their members to all the visits, as once completed they had to detail their experiences in the form of a series of case studies as a group activity in class. There was one case study for each visit. Visits were planned from the perspective of a taught and evaluated group activity. The necessity for autonomy in the internal organization of the groups involved students working together in a cooperative manner based on collaborative techniques that enabled each of the activities to be brought to a full conclusion (Deiglmayr \& Spada, 2011), (Kirschner, 2001). The public presentation of the case studies was mandatory and was undertaken in a specific classroom suitable for this type of group activity (Schmeck, Geisler-Brenstein, \& Cercy, 1991).

Visits were always carried out with the guidance of external advisors (F. Lawrenz, 2003). These tutors could belong to public institutions with knowledge in the area of the case studies or to the institutions visited by the students (Salleh \& Omar, 2013), (Jamaluddin et al., 2013), (Crawford, French, \& Lloyd-Walker, 2013). The evaluating committee was composed by teachers who worked on a rotary basis. In total, there were 10 committee members during the three years, shared between university teachers, businesses experts associated with the activities, or external advisors to the university. The staff that formed part of the committee belonged to the following professional profiles:

1. Golf courses

2. Hotel complexes

3. Water purification plants 

4. Quarry construction
5. Wind farms
6. Polo fields
7. Municipal, provincial and regional administration

The organization of the visits was carried out according to the following dynamic:

The university teachers were in charge of introducing the topic of the visit and the external advisors in collaboration with the universities guided and oversaw the visit "in situ". The external advisor assumed then a double role: on one hand, they provided guidance during the visit and on the other hand they were part of the committee that evaluated the learning of the content in accordance with the pre-established rubric.

The effectiveness of this activity was guaranteed by the establishment of a teaching-learning model that is based on three phases: a pre-visit, the visit itself and a post-visit. The pre-visit stage refers to the in class sessions in which students are prepared for the visit. Here the most relevant points to take into consideration during the visit are coordinated. During the "visit" phase students need to apply the aspects discussed during the previous phase. In the "post-visit" phase, which is carried out in the classroom, the experience and concepts covered and learnt during the visit are applied to generate a case study under different conditions than those observed during the visit. This strategy creates a macro-activity that serves as a core aspect for the technical reports that the students will have to defend in front of a committee and under specific evaluation criteria.

Another evaluated activity was the attendance to formative seminars which covered crosscurricular themes complementary to the knowledge acquired during the course and which were necessary for completing the catalogue. The seminars, during the three years of experimentation, covered the possible necessities of students with regard to aspects such as the design of web pages for the presentation of work, the use of computer applications and calculating tools, graphic design and the economic evaluation of projects. The formative seminars were geared towards providing a means of improving the quality and clarity of the final oral presentations.

In addition to the previously mentioned tasks, another series of evaluable activities was developed. As an example, the progress tests can be considered, which has an individual nature and has had a significant positive feedback on the final qualification scale of this subject (Chi, Siler, Jeong, Yamauchi, \& Hausmann, 2001). Thus, all students must be subjected to one or various exercises in which theoretical-practical concepts learnt during the performance of the activities are assessed. With this methodology, a comparative group-individual learning model is established that influences the detailing and defense of the final report and, as a result, the final qualification achieved.

This final activity is closely related to the preliminary preparation of the project presentation and led to a hypothesized improvement in the result of the final presentation. This took the form of the inclusion of an additional phase similar to a preliminary presentation. This strategy contributed to correct errors made during the first steps of the generation of the technical report. The activity was evaluated by assigned tutors and was useful for consolidating concepts and 
outlining with more clarity the trajectory of the final report (Soares et al., 2013), (Jamaluddin et al., 2013). This important intermediate phase was included in response to student's requests collected during previous initiatives in which suggestions regarding the improving of formation and contents were asked. The students requested that the evaluation of the final project was not based on the results achieved in the single day when their reports were defended, which also had a heavy weighting in the final mark. For this reason, presentation of reports was divided into two parts. The first was called "Preliminary Report Presentation" and was carried out as a defense of the report to the tutor and the other groups involved. The second part called "Final Presentation of Results" was more definitive. Both parts have an assigned weighting based on rubrics, with the higher weighting corresponding to the Final Presentation. An incremental improvement in the grades achieved annually was found.

The most noteworthy innovatory factor during this period is the system of multi-level evaluation based on rubric documents. This system involves every participant agent in the process of student evaluation, including self-evaluation and peer evaluation tests (Harris \& Brown, 2013). Via the combination of sub-evaluations to make up the final assessment a higher objectivity and robustness in the process is sort. These areas are discussed in the following sections. The key factors of success are found in (amongst others) aspects such as class participation, quality of the presented work, attitude and aptitude of the students and final evaluated qualifications (Brahimi, Dweiri, Al-Syouf, \& Khan, 2013).

\section{SYSTEM OF EVALUATION AND ANALYSIS OF FEASIBILITY}

Teaching innovation is not only focused on studying and redesigning specific methodologies such as those previously described. It also concerns their analysis and evaluation of their impact over the students. The indicators that have been put into place in this report have been incredibly varied. Firstly, the methods of collaborative/cooperational learning have been evaluated (Deiglmayr \& Spada, 2011). In general, they are considered by the authors to be a teaching methodology based on the belief that learning increases when the students develop cooperative skills for learning, problem solving and carrying out meaningful activities (Mulder, Lazonder, \& de Jong, 2014), (Patricia L. Linn,Adam Howard, 2004).

In order to conduct the evaluation, a Rubric of Evaluation (RE) was designed, which allows to conduct a feasibility study of the evaluation criteria that are used as a scale in the grading of the presentation of final projects (Hoyt, 2000). This RE contains a set of evaluation criteria that influences the skill areas presented to the students. The objective of this document is to propose a standard of evaluation applicable to future degree projects, not only for bachelors but also for masters. With this aim in mind, various levels of evaluation have been perform (Dochy, 2001), (Dochy, 2006).

Evaluation University Professor - Student "UP-S", (Lucas Yagüe et al., 2008)

Evaluation External Expert - Student "EE-S", (Frances Lawrenz et al., 2012)

Peer Evaluation - Student-Student "S-S", (Patri, 2002), (Harris \& Brown, 2013)

Self-Assessment- "SA", (Brown, 2005), (Khonbi \& Sadeghi, 2013), (Barrett, 2007) 
The multilevel evaluation system generates a probability table composed by all the results achieved during the study period. The grades were obtained over the same set of evaluation criteria, which once organized, were statistically analyzed. The analysis of the results obtained from the data processing reveals whether the evaluation criteria are robust enough to allow their maintenance, whether they are essential or they may be replaced instead.

For the design of the feasibility study, data of 180 students $(N=180)$ who took the pilot course were processed. The analysis was applied to the results of the combination of five evaluation variables collected in the rubric. These variables corresponded to five strategic learning scales $(4,5)$ with a score range from 0 to 10.

The five initial evaluation variables and their weighting were as follows:

\author{
Committed Errors (10\%) \\ Defense of questions requested by the committee (20\%) \\ Submitted documentation (40\%) \\ Speech skills (10\%) \\ Clarity and quality of the presentation (20\%)
}

The final grade will be the result of applying a $45 \%$ weight to the defense (in accordance with the variables listed previously), with the remaining $55 \%$ coming from the score obtained in other activities conducted during the course, which were described above. Finally, these variables were compared at each evaluation level: UP-S, EE-S, S-S, SA.

The feasibility of the instrument was calculated based on the statistic named "Cronbach's alpha" and a threshold of a=0,7 according to (Hernández-Ramos, Martínez-Abad, García Peñalvo, Esperanza Herrera García, \& Rodríguez-Conde, 2014), (T.-Y. Chen, Chang, \& Yeh, 2004), and using the statistics package SPSS Statistics V.21 (IBM, 2012).

The "Cronbach's alpha" coefficient is a measurement of internal consistency, based on the average correlations amongst variables (Cortina, 1993), (Peterson, 1994), (Hogan, 2004). One of the advantages of this statistical is that it allows to evaluate how much the feasibility of the test would improve (or worsen) if a specific variable were excluded. Other feasibility methods could be also applied, such as the KR-20 coefficient by Kuder-Richardson, or the division by halves (Leonard S. Feldt, 1969), (Adalberto Campo-Arias y Heidi C. Oviedo, 2008). However, the advantage of the coefficient lies in its simplicity, as the measurement is applied and the coefficient is calculated. The application of the coefficient therefore requires one simple administration of the measuring instrument and values between 0 and 1 are obtained.

\title{
4. RESULTS
}

According to the described procedure, a table composed by the aggregated marks obtained by students enrolled in the target course and coming from the results of implementing the evaluation rubric activity during the defense of the Master GIA is used. Data are processed and the following results for the different levels of evaluation were obtained: 


\section{LEVEL UP-S:}

Table 2. Processing summary cases in the UP-S level

\begin{tabular}{|l|l|c|c|}
\hline \multicolumn{2}{|c|}{} & $\mathbf{N}$ & \% \\
\hline \multirow{4}{*}{ Cases } & Valid & 180 & 84,9 \\
\cline { 2 - 4 } & Excluded & 32 & 15,1 \\
\cline { 2 - 4 } & Total & 212 & 100,0 \\
\hline \multicolumn{2}{|c|}{${ }^{\text {a. }}$ Eliminated by based on all process variables list. } \\
\hline
\end{tabular}

As shown in Table 2, 180 students out of the initial 212 could be considered as valid cases, once filtered by the statistical tool. This indicated a value very close to $85 \%$ efficiency during the process of data collection and preparation.

Table 3. Statistical elements.

\begin{tabular}{|l|c|c|c|}
\hline \multicolumn{1}{|c|}{ Items } & Average & Standard variaton & N \\
\hline ERRORS & 8,64 & 1,11 & 180 \\
\hline PRESENTATION (DEFENCE) & 9,61 &, 59 & 180 \\
\hline DOCUMENTATION & 8,45 &, 70 & 180 \\
\hline ATTITUDE & 8,54 &, 76 & 180 \\
\hline EXHIBITION & 8,14 &, 97 & 180 \\
\hline
\end{tabular}

Table 4. Reliability Analysis.

\begin{tabular}{|c|c|c|}
\hline Cronbach's alpha & $\begin{array}{c}\text { ronbach's alpha based in the ítems } \\
\text { definied }\end{array}$ & Item' s numbers \\
\hline, 635 &, 642 & 5 \\
\hline
\end{tabular}

Table 3 shows the average and standard deviations of the variables used whereas Table 4 summarizes the final alpha value, which in this case is $0.635<0.7$. This value indicates a low internal consistency of the evaluation criteria used (DeVellis, 2005). Due to the low feasibility, one of the criteria can be discarded (Vallejo, 2006). Moreover, Table 3 shows the similarity of the alpha coefficient for standardized elements, namely, the statistic calculated from correlations. This similarity between the values denotes the accuracy of the comparison between the variances of the elements.

In order to select the variable which, once removed, could enhance the value of the alpha coefficient, calculations indicated in Table 5 were performed. Indeed, if the variable DEFENCE is ignored, the minimum value in the reliability criterion is reached.

Table 5. Study variables contribution to the total.

\begin{tabular}{|l|c|c|}
\hline & $\begin{array}{c}\text { Squared multiple } \\
\text { correlation }\end{array}$ & $\begin{array}{c}\text { Cronbach's alpha if item } \\
\text { deleted }\end{array}$ \\
\hline ERRORS &, 109 &, 652 \\
\hline PRESENTATION (DEFENCE) &, 081 &, 707 \\
\hline DOCUMENTATION &, 538 &, 500 \\
\hline ATTITUDE &, 554 &, 463 \\
\hline EXHIBITION &, 401 &, 545 \\
\hline
\end{tabular}

Following this recommendation, such variable is removed and data reprocessed accordingly. For this new analysis, data were filtered without considering the marks obtained in the variable 
"Defence" and the result reaches 184 possible cases, which reveals a further increase in the efficiency of the filtering process (Table 6).

Table 6. Processing summary cases in the UP-S level regardless of the variable "Defence"

\begin{tabular}{|l|c|c|c|}
\hline \multicolumn{2}{|c|}{} & $\mathbf{N}$ & $\mathbf{\%}$ \\
\hline \multirow{3}{*}{ Cases } & Valid & 184 & 86,8 \\
\cline { 2 - 4 } & Excluded & 28 & 13,2 \\
\cline { 2 - 4 } & Total & 212 & 100,0 \\
\hline
\end{tabular}

Under these new conditions, the analysis provides a value of alpha coefficient equal to 0.707 , as shown in Table 7.

Table 7. Results of analysis without the variable "Defence."

\begin{tabular}{|c|c|c|}
\hline Cronbach's alpha & $\begin{array}{c}\text { Cronbach's alpha based in } \\
\text { the ítems definied }\end{array}$ & Item' s numbers \\
\hline, 707 &, 750 & 4 \\
\hline
\end{tabular}

Once the minimum objective is achieved, an improvement of the alpha coefficient can be proposed. Table 8 summarizes the results of reliability analysis without the variable "Defence". Furthermore, the alpha coefficient considerably improves and reaches the value of 0.806 if the variable "ERROR" is also removed.

Table 8. Statistical variables contribution to the total without one of its initial variables.

\begin{tabular}{|l|c|c|}
\hline & Squared multiple correlation & $\begin{array}{c}\text { Cronbach's alpha if item } \\
\text { deleted }\end{array}$ \\
\hline ERRORS &, 098 &, 806 \\
\hline DOCUMENTATION &, 545 &, 596 \\
\hline ATTITUDE &, 559 &, 559 \\
\hline EXHIBITION &, 366 &, 613 \\
\hline
\end{tabular}

Therefore, for an assessment based on the level UP-S, the three variables mostly contributing to the reliability of the evaluation process are:

- documentation provided

- speech and attitude,

- Clarity and quality of the exposition.

To complete the evaluation process, it is necessary to extend the reliability analysis to the other three levels of evaluation.

\section{LEVEL EE-S:}

Table 9. Processing summary level where EE-S 


\begin{tabular}{|l|l|c|c|}
\hline \multicolumn{2}{|c|}{} & $\mathbf{N}$ & $\mathbf{\%}$ \\
\hline \multirow{3}{*}{ Cases } & Valid & 193 & 92,0 \\
\cline { 2 - 4 } & Excluded & 17 & 8,1 \\
\cline { 2 - 4 } & Total & 212 & 100,0 \\
\hline
\end{tabular}

As shown in Table 9, 193 students out of the initial 212 could be considered as valid cases, once filtered by the statistical tool. This indicates a $92 \%$ efficiency in the process of data collection and preparation.

Table 10. Reliability Analysis in the EE-S level.

\begin{tabular}{|c|c|c|}
\hline Cronbach's alpha & $\begin{array}{c}\text { Cronbach's alpha based in the ítems } \\
\text { definied }\end{array}$ & Item' s numbers \\
\hline, 770 &, 739 & 5 \\
\hline
\end{tabular}

The alpha value for this level is presented in Table 10. The coefficient shows a value higher than 0.77 and, according to Table 11, if the variables EXPOSURE and ERRORS are subsequently ignored the reliability analysis increases.

Table 11. Statistical contribution to the total variables in the EE-S level.

\begin{tabular}{|l|r|}
\hline & $\begin{array}{c}\text { Cronbach's alpha if item } \\
\text { deleted }\end{array}$ \\
\hline ERRORS &, 801 \\
\hline PRESENTATION (DEFENCE) &, 604 \\
\hline DOCUMENTATION &, 604 \\
\hline ATTITUDE &, 693 \\
\hline EXHIBITION &, 812 \\
\hline
\end{tabular}

This result represents the lowest significance that this variable provides for the evaluation process and is coherent with the level of previous evaluation (UP-S) with respect to the unreliability of the variable "ERROR".

\section{LEVEL S-S:}

Table 12. Processing summary level where S-S

\begin{tabular}{|l|l|c|c|}
\hline \multicolumn{2}{|c|}{} & $\mathbf{N}$ & \% \\
\hline \multirow{2}{*}{$\begin{array}{l}\text { Q2Cas } \\
\text { es }\end{array}$} & Valid & 179 & 84,4 \\
\cline { 2 - 4 } & Excluded & 31 & 14,8 \\
\cline { 2 - 4 } & Total & 212 & 100,0 \\
\hline
\end{tabular}

As indicated in Table 12, 179 students out of the initial 212 could be considered as valid cases, once filtered by the statistical tool. This indicates an $85 \%$ efficiency in the process of data collection and preparation.

Table 13. Reliability Analysis in the level S-S.

\begin{tabular}{|c|c|c|}
\hline Cronbach's alpha & $\begin{array}{c}\text { Cronbach's alpha based in } \\
\text { the ítems definied }\end{array}$ & $\begin{array}{c}\text { Item's } \\
\text { numbers }\end{array}$ \\
\hline, 660 &, 814 & 5 \\
\hline
\end{tabular}


The alpha value for this level is shown in Table 13. This coefficient reaches a value lower than 0.7, which invalidates the proposed evaluation criteria. Elimination of the variable DEFENCE is then suggested in order to reach the reliability threshold (Table 14).

Table 14. Statistical contribution to the total variables in the level S-S

\begin{tabular}{|l|c|c|}
\hline & $\begin{array}{c}\text { Corrected total-item } \\
\text { correlation }\end{array}$ & $\begin{array}{c}\text { Cronbach's alpha if } \\
\text { item deleted }\end{array}$ \\
\hline ERRORS &, 715 &, 529 \\
PRESENTATION (DEFENCE) &, 174 &, 874 \\
DOCUMENTATION &, 420 &, 606 \\
ATTITUDE &, 631 &, 549 \\
EXHIBITION &, 715 &, 529 \\
\hline
\end{tabular}

This finding highlights the limited contribution that this variable provides to the evaluation process in the level S-S, certainly a contribution hard to be evaluated and shows discrepancy with respect to the levels previously analyzed.

\section{LEVEL SA:}

Table 15. Processing summary cases in the level SA

\begin{tabular}{|l|l|c|c|}
\hline \multicolumn{2}{|c|}{} & $\mathbf{N}$ & \% \\
\hline \multirow{3}{*}{ Cases } & Valid & 178 & 84,0 \\
\cline { 2 - 4 } & Excludes & 32 & 15,2 \\
\cline { 2 - 4 } & Total & 212 & 100,0 \\
\hline
\end{tabular}

As summarized in Table 15, 178 students out of the initial 212 could be used as valid cases, once filtered by the statistical tool. This indicates an $84 \%$ efficiency in the process of data collection and preparation.

Table 16. Reliability Analysis in the level SA.

\begin{tabular}{|c|c|c|}
\hline Cronbach's alpha & $\begin{array}{c}\text { Cronbach's alpha based in } \\
\text { the ítems definied }\end{array}$ & $\begin{array}{c}\text { Item' s } \\
\text { numbers }\end{array}$ \\
\hline, 480 &, 450 & 5 \\
\hline
\end{tabular}

Finally, the value of the alpha coefficient for the level of self-assessment is shown in Table 16. The reliability study of the criteria analyzed results in a coefficient value below the 0.7 ratio and, according to Table 17, elimination of some of the variables does not improve the analysis.

Table 17. Statistical contribution to the total variables in the level SA.

\begin{tabular}{|l|c|c|}
\hline & $\begin{array}{c}\text { Squared multiple } \\
\text { correlation }\end{array}$ & $\begin{array}{c}\text { Cronbach's alpha if } \\
\text { item deleted }\end{array}$ \\
\hline ERRORS &, 031 &, 506 \\
\hline PRESENTATION (DEFENCE) &, 139 &, 364 \\
\hline DOCUMENTATION &, 119 &, 394 \\
\hline
\end{tabular}




\begin{tabular}{|l|l|l|}
\hline ATTITUDE &, 164 &, 354 \\
\hline EXHIBITION &, 111 &, 446 \\
\hline
\end{tabular}

This result reveals a poor reliability of the evaluation criteria proposed within the level of student self-assessment. This result does not coincide with other levels analyzed where this selfassessment level is often not very reliable (Khonbi \& Sadeghi, 2013), (Harris \& Brown, 2013) and agrees with previous studies that indicate the limited capacity for students to assess themselves. This feature must be certainly a key factor to take into account in future studies on rubrics.

\section{CONCLUSIONS}

1. The application of a Catalogue or portfolio of tutored and Evaluable activities can be considered as a good alternative to the development of the teaching of certain aspects related to Final Degree or Masters projects, as the pilot approach obtained with the course "Organization and Project Management" has revealed the goodness of such methodology.

2. Skills promoted by this set of activities can be very useful to students who face the future EDP since, in many cases; they will serve as test - training actions.

3. The case studies have been particularly useful for addressing theoretical assumptions in a real scenario that is modified to be relevant for students. They have also led to decrease the distance often encountered between the theory and practice. The implementation of each study case has become a specialty of the degree itself.

4. The application of different learning resources, such as group tutoring, the library as a meeting place for sharing, enforcement of speech in defence of the work performed, monitoring of group and individual evolution and reinforcement some aspects seminars have resulted in a catalogue of tutored and evaluable activities, which is robust, balanced, motivating and effective for achieving the competencies and skills that have been raised since the beginning.

5. The rubric document raised here with a multi-level assessment presents reliability, expressed by the Cronbach's alpha statistic, which is based broadly on three variables: documentation submitted, speech skills and expository clarity and quality. Indeed, the assessment levels UP-S and EE-S revealed a poor contribution of the variables "DEFENCE" and "ERRORS". In the assessment level S-S, an adequate reliability is also reached by ignoring the variable "DEFENCE". This is not the case of the assessment level $\mathrm{SA}$, which shows the lowest reliability analysis, in agreement with previous studies.

\section{REFERENCES}


Apodaca, P., \& Grad, H. (2005). The dimensionality of student ratings of teaching: integration of uni- and multidimensional models. Studies in Higher Education, 30(6), 723-748. doi:10.1080/03075070500340101

Barrett, H. C. (2007). Researching Electronic Portfolios and Learner Engagement: The REFLECT Initiative. Journal of Adolescent \& Adult Literacy, 50(6), 436-449. doi:10.1598/JAAL.50.6.2

Başbay, M., \& Ateş, A. (2009). The reflections of student teachers on project based learning and investigating self evaluation versus teacher evaluation. Procedia - Social and Behavioral Sciences, 1(1), 242-247. doi:10.1016/j.sbspro.2009.01.044

Brahimi, N., Dweiri, F., Al-Syouf, I., \& Khan, S. a. (2013). Cooperative Education in an Industrial Engineering Program. Procedia Social and Behavioral Sciences, 102(Ifee 2012), 446-453. doi:10.1016/j.sbspro.2013.10.760

Bredin, K., \& Söderlund, J. (2013). Project managers and career models: An exploratory comparative study. International Journal of Project Management, 31(6), 889-902. doi:10.1016/j.jproman.2012.11.010

Brennan, D. (2006). Design-Operation Interface in Chemical Engineering. Education for Chemical Engineers, 1(1), 95-100. doi:10.1205/ece06013

Brown, A. (2005). Self-assessment of writing in independent language learning programs: The value of annotated samples. Assessing Writing, 10(3), 174-191. doi:10.1016/j.asw.2005.06.001

Chen, D., Li, Z., \& Wang, T. (2014). Exploration and practice: A competition based project practice teaching mode. Mechatronics, 24(2), 128-138. doi:10.1016/j.mechatronics.2013.12.009

Chen, T.-Y., Chang, P.-L., \& Yeh, C.-W. (2004). A study of career needs, career development programs, job satisfaction and the turnover intentions of R\&D personnel. Career Development International, 9(4), 424-437. doi:10.1108/13620430410544364

Chi, M. T. H., Siler, S. a., Jeong, H., Yamauchi, T., \& Hausmann, R. G. (2001). Learning from human tutoring. Cognitive Science, 25(4), 471-533. doi:10.1207/s15516709cog2504_1

Cortina, J. M. (1993). What is coefficient alpha? An examination of theory and applications. Journal of Applied Psychology, 78, 98104.

Crawford, L., French, E., \& Lloyd-Walker, B. (2013). From outpost to outback: project career paths in Australia. International Journal of Project Management, 31(8), 1175-1187. doi:10.1016/j.ijproman.2013.03.003

Deiglmayr, A., \& Spada, H. (2011). Training for fostering knowledge co-construction from collaborative inference-drawing. Learning and Instruction, 21(3), 441-451. doi:10.1016/j.learninstruc.2010.06.004

Delgado, M. A., \& Fonseca-Mora, M. C. (2010). The use of co-operative work and rubrics to develop competences. Education for Chemical Engineers, 5(3), e33-e39. doi:10.1016/j.ece.2010.05.002

DeVellis, R. F. (2005). Encyclopedia of Social Measurement Chapter: Inter-Rater Reliability. Encyclopedia of Social Measurement (pp. 317-322). Elsevier. doi:10.1016/B0-12-369398-5/00095-5

Dochy, F. (2001). A new assessment era: different needs, new challenges. Learning and Instruction, 10, 11-20. doi:10.1016/S09594752(00)00022-0

Dochy, F. (2006). INTRODUCTION ENHANCING STUDENT LEARNING THROUGH ASSESSMENT : ALIGNMENT BETWEEN LEVELS OF ASSESSMENT AND. Studies in Educational Evaluation, 32, 171-179. doi:10.1016/i.stueduc.2006.08.003

Dunbar, N. E., Brooks, C. F., \& Kubicka-Miller, T. (2006). Oral Communication Skills in Higher Education: Using a Performance-Based Evaluation Rubric to Assess Communication Skills. Innovative Higher Education, 31(2), 115-128. doi:10.1007/s10755-0069012-x

Gaubatz, N. B. \&, \& Centra, J. A. (2000). The Journal of Higher Education, Vol. 71, No. 1 (Jan. - Feb., 2000), pp. 17-33. Retrieved April 25, 2014, from http://www.jstor.org/discover/10.2307/2649280?uid=3737952\&uid=2\&uid=4\&sid=21104064608593 
Gómez-Ruiz, M.-Á., Rodríguez-Gómez, G., \& Ibarra-Sáiz, M. S. (2013). Desarrollo de las competencias básicas de los estudiantes de Educación Superior mediante la e-Evaluación orientada al aprendizaje. RELIEVE - Revista Electrónica de Investigación Y Evaluación Educativa, 19(1). doi:10.7203/relieve.19.1.2457

Harris, L. R., \& Brown, G. T. L. (2013). Opportunities and obstacles to consider when using peer- and self-assessment to improve student learning: Case studies into teachers' implementation. Teaching and Teacher Education, 36, 101-111. doi:10.1016/j.tate.2013.07.008

Hernández-Ramos, J. P., Martínez-Abad, F., García Peñalvo, F. J., Esperanza Herrera García, M., \& Rodríguez-Conde, M. J. (2014). Teachers' attitude regarding the use of ICT. A factor reliability and validity study. Computers in Human Behavior, 31, 509516. doi:10.1016/j.chb.2013.04.039

Hogan, T. P. (2004). An Empirical Study of Reporting Practices Concerning Measurement Validity. Educational and Psychological Measurement, 64(5), 802-812. doi:10.1177/0013164404264120

Hoyt, W. T. (2000). Rater bias in psychological research: When is it a problem and what can we do about it? Psychological Methods, 5(1), 64-86.

Huemann, M., Keegan, A., \& Turner, J. R. (2007). Human resource management in the project-oriented company: A review. International Journal of Project Management, 25(3), 315-323. doi:10.1016/j.ijproman.2006.10.001

lacobucci, D., \& Duhachek, A. (2003). Advancing Alpha: Measuring Reliability With Confidence. Journal of Consumer Psychology, 13(4), 478-487. doi:10.1207/S15327663JCP1304_14

IBM. (2012). IBM SPSS v.21.

Jamaluddin, N., Ayob, A., Osman, S. A., Omar, M. Z., Kofli, N. T., \& Johar, S. (2013). Undergraduate Industrial Training Experience: A Win-win Situation for Students, Industry and Faculty. Procedia - Social and Behavioral Sciences, 102(Ifee 2012), 648-653. doi:10.1016/j.sbspro.2013.10.783

Khonbi, Z. A., \& Sadeghi, K. (2013). The Effect of Assessment Type (Self Vs. Peer) on Iranian University EFL Students' Course Achievement. Procedia - Social and Behavioral Sciences, 70, 1552-1564. doi:10.1016/j.sbspro.2013.01.223

Kirschner, P. A. (2001). Using integrated electronic environments for collaborative teaching / learning \&, 2(August 1999), 1-9.

Krajcik, J.S. \& Blumenfeld, P. (2006). the cambridge handbook learning sciences.pdf.

Lawrenz, F. (2003). Evaluative Site Visits: A Methodological Review. American Journal of Evaluation, 24(3), 341-352. doi:10.1177/109821400302400304

Lawrenz, F., Thao, M., \& Johnson, K. (2012). Expert panel reviews of research centers: the site visit process. Evaluation and Program Planning, 35(3), 390-7. doi:10.1016/j.evalprogplan.2012.01.003

Leonard S. Feldt. (1969). A test of the hypothesis that cronbach's alpha or kuder-richardson coefficent twenty is the same for two tests. Psychometrika September 1969, Volume 34, Issue 3, Pp 363-373, 363. Retrieved from http://citations.springer.com/item?doi=10.1007/BF02289364

Lucas Yagüe, S., García Encina, P. A., Bolado Rodríguez, S., García Cubero, M. T., González Benito, G., \& Urueña Alonso, M. Á. (2008). Teaching and learning strategies and evaluation changes for the adaptation of the Chemical Engineering degree to EHES. Education for Chemical Engineers, 3(1), e33-e39. doi:10.1016/j.ece.2008.01.002

Manlove, S., Lazonder, A. W., \& Jong, T. de. (2009). Trends and issues of regulative support use during inquiry learning: Patterns from three studies. Computers in Human Behavior. doi:10.1016/j.chb.2008.07.010

Markom, M., Khalil, M. S., Misnon, R., Othman, N. A., Abdullah, S. R. S., \& Mohamad, A. B. (2011). Industrial Talk and Visit for Students. Procedia - Social and Behavioral Sciences, 18, 674-682. doi:10.1016/j.sbspro.2011.05.099 
Mulder, Y. G., Lazonder, A. W., \& de Jong, T. (2011). Comparing two types of model progression in an inquiry learning environment with modelling facilities. Learning and Instruction, 21(5), 614-624. doi:10.1016/j.learninstruc.2011.01.003

Mulder, Y. G., Lazonder, A. W., \& de Jong, T. (2014). Using heuristic worked examples to promote inquiry-based learning. Learning and Instruction, 29, 56-64. doi:10.1016/j.learninstruc.2013.08.001

Nasser, F., \& Hagtvet, K. a. (2006). Multilevel Analysis of the Effects of Student and Instructor/Course Characteristics on Student Ratings. Research in Higher Education, 47(5), 559-590. doi:10.1007/s11162-005-9007-y

Patri, M. (2002). The influence of peer feedback on self and peer-assessment of oral skills. Language Testing, 19(2), $109-131$. doi:10.1191/0265532202It224oa

Patricia L. Linn,Adam Howard, E. M. (2004). Handbook for Research in Cooperative Education and Internships. Retrieved from http://books.google.com/books?hl=es\&lr=\&id=t-_-jqZX7gAC\&pgis=1

Peterson, R. A. (1994). A meta-analysis of Cronbach's alpha coefficient. Journal of Consumer Research, 21, 381-391. Retrieved from http://www.jstor.org/discover/10.2307/2489828?uid=3737952\&uid=2\&uid=4\&sid=21104065065773

Ragusa, G., \& Lee, C. T. (2012). The impact of focused degree projects in chemical engineering education on students' research performance, retention, and efficacy. Education for Chemical Engineers, 7(3), e69-e77. doi:10.1016/j.ece.2012.03.001

Rezaev, A. V. (2010). International Encyclopedia of Education. International Encyclopedia of Education (pp. 772-778). Elsevier. doi:10.1016/B978-0-08-044894-7.00169-X

Sakarya, a. O., \& Kahraman, Z. E. H. (2011). Collaboration in Bologna Process: The Experience of Department of Interior Architecture in cankaya University. Procedia - Social and Behavioral Sciences, 30, 1312-1317. doi:10.1016/j.sbspro.2011.10.255

Salán, M. N., Martinez-Martinez, M., Portet, E., \& Torra, I. (2012). RIMA Project: Activities and Initiatives Communion and Sharing in Educational Innovation at UPC-BARCELONATECH. Procedia - Social and Behavioral Sciences, 46, 2284-2288. doi:10.1016/j.sbspro.2012.05.471

Salleh, M. S., \& Omar, M. Z. (2013). University-industry Collaboration Models in Malaysia. Procedia - Social and Behavioral Sciences, 102(Ifee 2012), 654-664. doi:10.1016/j.sbspro.2013.10.784

Schmeck, R. R., Geisler-Brenstein, E., \& Cercy, S. P. (1991). Self-Concept and Learning: the revised inventory of learning processes. Educational Psychology, 11(3-4), 343-362. doi:10.1080/0144341910110310

Siu, K. W. M. (2007). Balance in Research and Practice : the Reform of Research Studies in Industrial and Product Design, 11(1).

Soares, F. O., Sepúlveda, M. J., Monteiro, S., Lima, R. M., \& Dinis-Carvalho, J. (2013). An integrated project of entrepreneurship and innovation in engineering education. Mechatronics, 23(8), 987-996. doi:10.1016/j.mechatronics.2012.08.005

Umphress, V. J., Lambert, M. J., Smart, D. W., Barlow, S. H., \& Clouse, G. (1997). Concurrent and Construct Validity of the Outcome Questionnaire. Journal of Psychoeducational Assessment, 15(1), 40-55. doi:10.1177/073428299701500104

Vallejo, P. M. (2006). Medición de actitudes en psicología y educación: Construcción de escalas y problemas metodológicos. Retrieved from http://books.google.com/books?hl=es\&lr=\&id=bnATYNmjPOcC\&pgis=1

Van Der Merwe, a. . (2002). Project management and business development: integrating strategy, structure, processes and projects. International Journal of Project Management, 20(5), 401-411. doi:10.1016/S0263-7863(01)00012-6

Yeh, Y. (2012). A co-creation blended KM model for cultivating critical-thinking skills. Computers \& Education, 59(4), $1317-1327$. doi:10.1016/j.compedu.2012.05.017

Yeh, Y., Huang, L., \& Yeh, Y. (2011). Knowledge management in blended learning: Effects on professional development in creativity instruction. Computers \& Education, 56(1), 146-156. doi:10.1016/j.compedu.2010.08.011 
Yeh, Y., Yeh, Y., \& Chen, Y.-H. (2012). From knowledge sharing to knowledge creation: A blended knowledge-management model for improving university students' creativity. Thinking Skills and Creativity, 7(3), 245-257. doi:10.1016/j.tsc.2012.05.004 